\title{
Critical Analysis and Identity Construction of Chinese News Media from Transitivity Perspective
}

\author{
Yang $\mathrm{Liu}^{1} \&$ Wanxin $\mathrm{Jia}^{2}$ \\ ${ }^{1}$ Comprehensive English Teaching and Research Office, North China Electric Power University, Baoding, China \\ ${ }^{2}$ English Department, North China Electric Power University, Baoding, China \\ Correspondence: Wanxin Jia, English Department, North China Electric Power University, Baoding, 071000, \\ Hebei province, China.
}

Received: September 12, 2019

Accepted: October 25, 2019

Online Published: December 30, 2019

doi:10.5539/ies.v13n1p84

URL: https://doi.org/10.5539/ies.v13n1p84

\begin{abstract}
As the disseminator of information, news media play a vital role in the public speech community. Especially the mainstream English media in China, which not only carefully design the topic, content, and framework of news to broadcast information but also construct cultural identity and build China's image. Exemplified by a piece of news from China Daily, the present study analyzes its language features and function of transitivity system based on the theory of transitivity, and attempts to explore its implicit meaning and cultural identity beyond the literal text.
\end{abstract}

Keywords: cultural identity construction, critical discourse analysis, news discourse, transitivity

\section{Introduction}

Nowadays, the popularization and development of the internet have helped form a public discourse in which people have easier access to information acquisition and exchange. As the disseminator of information, news media also play an important role in modern society and help people to understand the world. With the continuous implementation of China's policy of opening up to the outside world, the role of domestic English news media in international communication is becoming more and more important. Reporters carefully choose words and design framework of news to broadcast information objectively but also improve China's international status and shape its image. Therefore, this paper makes a critical analysis of a piece of news from China Daily, one of the largest mainstream English media in China to explore its implicit meaning.

Many scholars at home and abroad have used the transitivity theory to analyze some literary works, and proved that this analysis model is very convincing in revealing characters' characteristics and thematic significance. And in this paper, transitivity theory is used to make a critical analysis of news discourse. Through exploring the language features of clauses in news discourse reveal the cultural identity beyond the literal text from the perspective of systemic-functional grammar.

\section{Cultural Identity Construction}

The concept of identity is complex and involves multiple disciplines. It firstly appears in sociology and refers to the social attributes of an individual or group. Later, psychologists define it as a person's social positioning towards others and himself (Bucholtz \& Hall, 2005). As the development of social pragmatics, it is believed that identity includes two aspects: one is the stable characteristics that have been formed before communication, and the other is the dynamic identity realized through discourse in communication (Tracy, 2002). Moreover, the definition of identity in sociocultural theory is elaborated as a kind of cultural or national sense of belonging, and this cultural identity is a country's unique characteristics and cultural imprint, which is the key to self-identity. With the continuous researches of multi-disciplinary, its definition is constantly updating, while there is a broad consensus that the identity not only has social attribute but also has communicative attribute; the construction of identity can be influenced by communicative environment and communicative object, and identity is selective (De Fina et al., 2008). This study focuses on the identity from the perceptive of pragmatics, analyzing the specific social identity reflected in a particular communication context and revealing its cultural values. 


\section{Theoretical Framework}

\subsection{Transitivity}

Halliday (1976) clarified the concept of transitivity from the perspective of systemic-functional grammar, which is different from that of traditional grammar. Transitivity in traditional grammar focuses on the relationship between the verb and its subsequent object. However, in systemic-functional grammar, transitivity refers to a system for describing the whole clause. From the experiential perspective, it uses language to talk about experience of the world (Thompson, 2013), and involves the process, participants, and the certain circumstance (Benson \& Greaves, 1987). There are a set of types, such as material processes, mental processes, relational processes, behavioral processes, verbal processes and existential processes.

Material processes are those involving doing something with some physical actions. For example, "draw", "hop", "swim" and so on. In this process, the doer of the action is named Actor, and another participant is named Goal.

Mental processes reflect the participant's internal world involving two participants. One is Senser and the other is Phenomenon. In this process, the tense is always simple form. For instance, "I believe...", "he convinces..." and so on.

Relational processes include two sub-types, they are, attributive and identifying relational processes, which indicate the relationship between two participants whose name is Carrier and the Attribute in attributive processes while in identifying relational processes is the Token and the Value.

Verbal processes refer to the movement of messages through language. In other words, saying something is a physical action that affects mental operation. Common verbs are "say", "praise", "claim" and so on. This process is related to Sayer, Receiver, and Verbiage consisting of a label for the language itself, and in certain cases, the participant is called Target.

Behavioral processes are intermediate between mental and material processes. It relates to certain human physiological processes. For example, "laugh" and "stare". There is only one participant in this process, that is, Behaver. In some cases, there may be another participant, Range.

Existential processes mean that something exists or happens. The clause has a distinct marker "there", or typically employs the verb such as "exist", "remain", "happen" and so on. Thus, the participant role associated with existential processes is Existent.

\subsection{Critical Discourse Analysis}

The concept of Critical Discourse Analysis was first shown in Language and Control (Fowler, Hodge, Kress, \& Trew, 1979). It adopts the viewpoint of systemic functional linguistics, which regards language as a social symbol, and combines with knowledge of various disciplines, such as psychology, stylistics, discourse analysis. As such, transitivity, a vital tool to analyze ideological meaning contained in the discourse, explores how language reflects the power relationship between the text producer and the text receiver and reveals the construction of cultural identity.

\section{Previous Researches Abroad and at Home}

Researches about critical discourse analysis abroad have abundant achievements. Fowler (1979) claimed that special attention should be paid to transitivity, coherence, modeling and so on in the critical analysis of discourse. Fairclough (1992) put forward the framework of critical discourse analysis, believing that any discourse has three dimensions: text, discourse practice, and social practice. Besides, overseas researches also involve various fields. For example, critical analysis of institutional and organizational discourses, multimedia or discourse critical analysis, social critical analysis of racial discrimination and so on.

In recent years, case analysis of news discourse with transitivity has developed rapidly in China. Domestic researches are mainly divided into three types. First, theoretical introduction and summary. Xin (2000) made a theoretical introduction to Critical Discourse Analysis, and briefly summarized some general principles and methods of critical linguistics. Second, analytical research on specific texts. For instance, Shan (2011) introduced theoretically the concept and steps of critical discourse analysis, and analyzed a piece of news in The New York Times, from the perspective of word selection, transitivity, discourse practice, and social function. Third, critical comparative analysis of news discourses. Y. Sun, and Z. Sun (2009) analyzed a piece of news from the Wall Street Journal, making a comparison between the original and translated statement. Furthermore, some researchers made a horizontal comparison of the reports with the same event in different texts. For example, Wang (2013) compared and analyzed the English texts of the same event. He chose two news reports on climate conference from China 
Daily and The New York Times, in order to analyze their construction strategy, while others made a longitudinal analysis, comparing and analyzing different texts reported by different newspapers (Jiang \& Gu, 2000).

\section{Transitivity Analysis of News Discourse}

This study analyzes the language features and function of the transitivity system of news discourse based on the theory of transitivity, and attempts to explore its implicit meaning and cultural identity beyond the literal text. The example news is from China Daily, named Crucial step forward taken for $5 G$ with commercial licenses with a total of 926 words and 86 clauses/processes. The following chart shows the transitivity of clauses and the distribution of each process clearly.

According to Table 1, Material processes are used the most frequently, accounting for $60 \%$. Verbal processes and verbal processes take the next place, with $24 \%$ and $15 \%$ respectively. Psychological processes account for the smallest proportion, only $1 \%$. And there are no behavioral processes or existential processes in this piece of news. Thus, this study will mainly discuss the features and function of the first four processes.

Table 1. Process distribution of crucial step forward taken for 5G with commercial licenses

\begin{tabular}{lcc}
\hline Process & Number & Percentage \\
\hline Material processes & 51 & $60 \%$ \\
Verbal processes & 21 & $24 \%$ \\
Relational processes & 13 & $15 \%$ \\
Mental processes & 1 & $1 \%$ \\
Behavioral processes & 0 & $0 \%$ \\
Existential processes & 0 & $0 \%$ \\
\hline
\end{tabular}

\subsection{Features and Functions of Material Processes}

Material processes describe physical actions and objective facts or situations. This process is used frequently, which reflects the characteristics of news discourse are that to describe objective facts, giving readers an impression of authenticity.

Example 1: The 5G licensing (Actor) will help deepen (Process: material) structural reform (Goal) (Circumstance), improve (Process: material) the level of social and economic informatization (Goal) and assist (Process: material) several leading companies (Goal) with global competitiveness (Circumstance).

Translation version: 5G 牌照的发放不仅有利于我国信息通信业深化供给侧结构性改革、助力提升经济社会 信息化水平，也有利于加快建设具有全球竞争力的世界一流企业。

Example 2: the ministry (Actor) will take (Process: material) key measures (Goal) to promote 5G application, strengthen (Process: material) industrial management, better allocate (Process: material) resources(Goal), encourage (Process: material) companies (Goal) to participate in 5G network constructions and further integrate $5 \mathrm{G}$ with vertical industries (Circumstance).

Translation version: 该部门将采取关键措施, 促进 $5 \mathrm{G}$ 应用, 加强产业管理, 合理分配资源, 鼓励企业参 与 $5 \mathrm{G}$ 网络建设, 进一步将 $5 \mathrm{G}$ 与垂直产业融合。

In this piece of news, material processes account for over half of all processes. Some verbs, such as "deepen", "improve", and "encourage", present the real situation to the public impartially, highlight the advantages of 5G, and show China's positive actions towards 5G. Use of parallel sentences highlights the importance of 5G and enhances emotions. Furthermore, the clauses, such as "leading companies with global competitiveness", and "to participate in $5 \mathrm{G}$ network constructions and further integrate $5 \mathrm{G}$ with vertical industries", reflect China's rapid development of science and technology, and create a positive image of China to readers.

\subsection{Features and Functions of Verbal Processes}

A prominent feature of news discourse is that journalists are always quoting the words of relevant people by using direct speech and indirect speech. The former can add authority and credibility, and the latter can express opinions indirectly by paraphrasing others' speech.

Example 3: China Unicom (Sayer) noted (Process: verbal) it will continue to welcome foreign companies to participate in domestic $5 \mathrm{G}$ construction (Verbiage).

Translation version: 中国联通表示, 我们一如既往地欢迎外国企业积极参与中国 5G 市场。 
Example 4: "China (Actor) has (Process: material) the confidence (Goal) to compete with foreign companies in the market (Circumstance)." Wang (Sayer) said (Process: verbal).

Translation version: 王表示: ”中国有信心在国际市场上与其他外国公司进行竞争”。

In news discourse, verbal processes reflect mental operation because journalists would quote the speech that they think is important. The Sayers of example 3 and 4 are representative. China Unicom is one of China's leading telecommunications companies, and Raymond Wang is a partner with global consultancy firm Roland Berger. Thus, quoting what they said can increase the credibility of the content. These two sentences both reflect an optimistic attitude towards 5G. More importantly, "continue to welcome" and "has the confidence to compete" imply China's tolerance when facing some western countries' doubts and criticism and open attitude to cooperate, constructing the identity as a major country in a delicate way.

\subsection{Features and Functions of Relational Processes}

Relational processes are the most convenient way for journalists to express their opinions, and affect people's cognition and belonging, so it is important to further explore the deep meaning beyond the literal text.

Example 5: China Mobile (Sayer) claimed (Process: verbal) its 5G services (Carrier) will be (Process: relational) available (Attribute) in more than 40 cities by the end of September (Circumstance).

Translation version: 中国移动称, 在今年 9 月底前, 公司将在超过 40 个城市内提供 $5 \mathrm{G}$ 服务。

Example 6: The 5G licensing (Token) will be (Process: identifying) a key step (Value) to build the country into a "cyber power" (Circumstance).

Translation version: 5G 牌照的发放将是中国成为” 网络强国” 的关键一步。

Relational processes indicate the relationship between two terms, so the selection of word is of great importance. The sentence of example 5 draws a blueprint of China's booming development. In example 6, the reporter employs "a key step" to identify the application of 5G, which indicates it is importance to the country's development and guides the public to take a positive attitude towards $5 \mathrm{G}$. These two sentences make readers full of hope for $5 \mathrm{G}$, creating a confident image as a major country.

\subsection{Features and Function of Mental Processes}

Mental processes can express the participant's inner feeling, so it can be identified into the process of feeling, knowing, sensing and wanting and so on.

Example 7: Many foreign telecom companies (Senser) applauded (Process: mental) the move and the country's commitment to international cooperation (Phenomenon).

Translation version: 许多外国电信公司对 $5 \mathrm{G}$ 以及中国对国际合作的承诺表示赞赏。

Mental processes show the participant's attitude or view to what happens, which is beneficial to guide readers to frame their ideology and value orientation. For example, this sentence reflects that many foreign telecom companies hold a positive attitude towards China's 5G. On the other hand, it expresses public expectations that hoping more countries will recognize the development of $5 \mathrm{G}$ in China. What's more, by comparing English version and Chinese version, it is found that English speakers always put words expressing people's attitude at the beginning, while Chinese prefer to put them in the end because we always state facts first and then make a comment, which is the difference between Chinese and English expressions, reflecting the different value.

\section{Discussion and Expectation}

Cultural identity is a kind of self-definition of a nation or a country, the foundation of which is the social and cultural mechanism such as language system and values (Xu, 2017). Language is a vital tool in communication, and language users can construct identity by the wording. For example, in news discourse, journalists not just report news; meanwhile, they can express their implicit meaning by choosing different words and selecting different processes. For those international journalists, they shoulder the reasonability to maintain the national positive image and make more people know the country. By analyzing this news, it is found that Chinese reporters use some writing strategies to guide readers to accept the ideas that they want to convey, and the content of the news show readers a positive image of China, make more people know about China and let China Voice go to the world.

However, intercultural communication would be affected by different values. For instance, language expression, writing logic, attitudes on some issues and so on. Thus, social media in China are expected to pay attention to the construction of local cultural identity and maintain national consciousness. Firstly, reporters are expected to improve English expression ability and information analysis ability, so that the accuracy and artistry of language 
use can be improved and Chinese culture can be better displayed to foreign readers. Second, in the face of cultural conflicts and diversity, they are expected to learn as many different cultures as possible to improve their cultural sensitivity, popularizing Chinese mainstream culture and building a good international image of China.

\section{Acknowledgments}

This paper is one of the research achievements of "Research on the Solution of the Contradiction between Chinese Cultural Promotion and Chinese Cultural Aphasia in College English Teaching" (No. HB18YY033) supported by Social Science Foundation of Hebei Province in 2018.

\section{References}

Benson, J. D., \& Greaves, W. S. (1987). A comparison of process types in Poe and Melville. In R. Seele, \& T. Threadgold (Eds.), Language Topics (p. 131). Amsterdam Philadelphia: John Benjamins Publishing Company. https://doi.org/10.1075/z.lt1.56ben

Bucholtz, M., \& K. Hall. (2005). Identity and interaction: A sociocultural linguistic approach. Discourse Studies, 7, 584-614. https://doi.org/10.1177/1461445605054407

De Fina, A. Schiffrin, D., \& Bamberg, M. (2008). Discourse and Identity. Cambridge: Cambridge University Press.

Fairclough, N. (1992). Discourse and Social Change. Cambridge: Polity Press.

Fowler, R., Hodge, B., Kress, G., \& Trew, T. (1979). Language and control. London: Routledge and Kegan Paul.

Halliday, M. A. K. (1994). An Introduction to Functional Grammar. London: Edward Arnold Publishers Limited.

Jiang, J., \& Gu, T. (2000). A Critical Linguistic analysis of English News Text. Journal of China West Normal University (Philosophy \& Social Sciences), 2, 69-71. https://doi.org/10.16246/j.cnki.51-1674/c.2000.02.014

Lustig, M. W., \& Koester, J. (Eds.). (2000). Among Us: Essays on Identity, Belonging and Intercultural Competence. New York: Longman.

Shan, S. (2011). Critical Discourse Analysis of News Discourse. Foreign Language Research, 6, 78-81. https://doi.org/10.16263/j.cnki.23-1071/h.2011.06.018

Sun, Y., \& Sun, Z. (2009). Critically Comparative Analysis of English and Chinese News Discourse from the Transitivity Perspective. Journal of Guizhou University (Social Sciences), 27, 113-117.

Thompson, G. (2013). Introducing Functional Grammar. Beijing, China: Foreign Language Teaching and Research Press.

Tracy, K. (2002). Everyday Talk: Building and Reflecting Identities. London: The Guilford Press.

Wang, G. (2013). Epistemological positioning and critical reading in news discourse: A case study of news reports in China Daily and New York Times. Shandong Foreign Language Teaching, 4, 37-42. https://doi.org/10.16482/j.sdwy37-1026.2013.04.001

Xin, B. (2000). Critical Linguistics and the Critical Analysis of English News. Foreign Language Education, 4, 44-48.

$\mathrm{Xu}$, Y. (2017). Study on the construction of cultural identity in English news reports by Chinese and American media. The Press, 20, 47-48.

\section{Copyrights}

Copyright for this article is retained by the author(s), with first publication rights granted to the journal.

This is an open-access article distributed under the terms and conditions of the Creative Commons Attribution license (http://creativecommons.org/licenses/by/4.0/). 